\title{
Training Mode for Master of Health Administration: Learning from North America
}

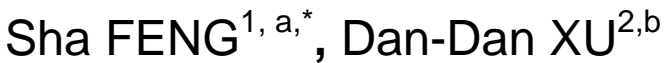 \\ ${ }^{1}$ Faculty of Medical Science, Jinan University, Guangzhou, China 510632 \\ ${ }^{2}$ School of Stomatology, Jinan University, Guangzhou, China 510632 \\ a2439770562@qq.com, b774576687@qq.com \\ *Corresponding author
}

Keywords: North America; Master of Health Administration; training mode

\begin{abstract}
The training mode for Master of Health administration has been mature among top universities in North America. It's mainly under the school of public health, which have long history and large scale. The training objectives for Master of Health Administration defined clearly and had specific settings for different majors. There were obvious differences between Research and Professional Practice graduate students. The curriculum mainly focused on basic and professional courses, paid much attention to the management and leadership training, and closely combined with the real world. Training mode for Master of Health Administration in China should be further determined to specify the training objectives, build competency-based curriculum system and develop practical ability.
\end{abstract}

\section{Introduction}

Public health degree education in North America has been in the forefront of the world, mainly education after college, which has no significant professional restrictions. The training of his master's degree in health management has been more mature and has been a great deal of health leaders in the region and the world. This article analyzed training mode for Master of Health Administration in the three world first-class university, including Harvard University, Johns Hopkins university and the university of Toronto, in order to provide valuable experience for China's Master of Health administration Reform.

\section{General Information of Public Health Schools In Northern America}

Three top universities in North America offered the specialty of health management, which were all under the school of public health. In general, the three public health institutes were characterized by the top globally, long history, rich teaching resources, and diverse disciplines (Table 1).

Founded in 1913, Harvard School of Public Health was the oldest public health college in the United States. In 2014, the Harvard School of Public Health officially changed its name to "Harvard T.H. Chan School of Public Health", in order to honor the foundation's donation to the Harvard School of Public Health. It consisted of nine academic departments, including Biostatistics, Environmental Health, Epidemiology, Genetics and Complex Diseases, Global Health and Population, Health Policy and Management, Immunology and Infectious Diseases, Nutrition, Social and Behavioral Sciences. Degree programs were designed to meet the specific needs of students with varying levels of experience and education, and with career goals focused on either professional practice or academia. There was also considerable flexibility within degree programs for students to shape the learning experience to match their own interests and aspirations ${ }^{[1]}$. Master's degrees covered Master of Public Health (MPH), Master in Health Care Management (MHCM), Master of Science (SM), while Doctoral degrees covered Doctor of Public Health (DrPH) and Doctor of Philosophy (PhD). 
Johns Hopkins School of Public Health was founded in 1916, and then in $2001 \mathrm{its}$ name was changed to the Johns Hopkins Bloomberg School of Public Health in honor of Michael Bloomberg for his financial support and commitment to the field of public health. It consisted of ten departments, including Biochemistry and molecular biology, Biostatistics, Environmental health and engineering, Epidemiology, Health, behavior and society, Health policy and management, International health, Mental health, W. Harry Feinstone Dept. of molecular microbiology and immunology, Population, family and reproductive health. For the student who has just completed undergraduate studies or the professional with a few years of experience, the Bloomberg School offered several master's degree programs, including Master of Applied Science (MAS), Master of Bioethics (MBE), Master of Health Administration (MHA), Master of Health Science (MHS), Master of Public Health (MPH), Master of Science in Public Health (MSPH), Master of Science (ScM), Master in Public Policy (MPP) ${ }^{[2]}$. In the meanwhile, Doctoral degree programs targeted students with specific career goals in public health research, teaching or leadership, including Doctor of Philosophy $(\mathrm{PhD})$, Doctor of Science $(\mathrm{ScD})$, and Doctor of Public Health (DrPH).

Founded in 1927, University of Toronto Dalla Lana School of Public Health was the third oldest School of Public Health in Northern America. The School was reborn in 2008 and renamed following Paul and Alessandra Dalla Lana's \$20-million gift in 2009. The School comprised five divisions (Biostatistics, Epidemiology, Clinical public health, Occupational \& environmental health, Social \& behavioral health sciences) and four institutes and centers. Master's degree offered a wide range of options to students, including Master of Public Health (MPH), Master of Science in Community Health (MSCCH), Master of Science (MSC), and Master of Health Science (MHSC). Multidisciplinary PhDs offered in four fields that expose students to the full breadth and depth of public health [3].

Table 1 General information of Public Health Schools in North America

\begin{tabular}{|c|c|c|c|c|c|}
\hline Country & $\begin{array}{l}\text { Name of } \\
\text { University }\end{array}$ & $\begin{array}{l}\text { Name of } \\
\text { School }\end{array}$ & $\begin{array}{l}\text { Established } \\
\text { year }\end{array}$ & Departments and institutes & $\begin{array}{l}\text { Degree } \\
\text { programs }\end{array}$ \\
\hline US & $\begin{array}{l}\text { Harvard } \\
\text { University }\end{array}$ & $\begin{array}{l}\text { Harvard } \\
\text { T.H.Cha } \\
\text { n School } \\
\text { of Public } \\
\text { Health }\end{array}$ & 1913 & $\begin{array}{l}\text { Biostatistics, Environmental Health, } \\
\text { Epidemiology, Genetics and Complex } \\
\text { Diseases, Global Health and Population, } \\
\text { Health Policy and Management, } \\
\text { Immunology and Infectious Diseases, } \\
\text { Nutrition, Social and Behavioral Sciences }\end{array}$ & $\begin{array}{l}\text { MPH } \\
\text { MHCM } \\
\text { DrPH SM } \\
\text { Ph.D. }\end{array}$ \\
\hline US & $\begin{array}{l}\text { Johns } \\
\text { Hopkins } \\
\text { University }\end{array}$ & $\begin{array}{l}\text { Johns } \\
\text { Hopkins } \\
\text { Bloombe } \\
\text { rg } \\
\text { School } \\
\text { of Public } \\
\text { Health }\end{array}$ & 1916 & $\begin{array}{l}\text { Biochemistry and molecular biology, } \\
\text { Biostatistics, Environmental health and } \\
\text { engineering, Epidemiology, Health, } \\
\text { behavior and society, Health policy and } \\
\text { management, International health, Mental } \\
\text { health, W. Harry Feinstone Dept of } \\
\text { molecular microbiology and immunology, } \\
\text { Population, family and reproductive } \\
\text { health }\end{array}$ & $\begin{array}{lr}\text { MAS } & \text { MBE } \\
\text { MHA } & \text { MHS } \\
\text { MPH } & \text { MSPH } \\
\text { ScM } & \text { MPP } \\
\text { Ph.D. } & \text { ScD } \\
\text { DrPH } & \end{array}$ \\
\hline Canada & $\begin{array}{l}\text { Toronto } \\
\text { University }\end{array}$ & $\begin{array}{l}\text { Dalla La } \\
\text { na Scho } \\
\text { ol } \\
\text { of Public } \\
\text { Health }\end{array}$ & 1927 & $\begin{array}{l}\text { Divisions: Biostatistics, Epidemiology, } \\
\text { Clinical public health, Occupational \& } \\
\text { environmental health, Social \& behavioral } \\
\text { health sciences; Institutes and Centers : } \\
\text { Institute of health policy, management \& } \\
\text { evaluation (IHPME), } \\
\text { Waakebiness-Bryce institute for } \\
\text { indigenous health (WBIIH), institute for } \\
\text { global health equity \& innovation } \\
\text { (IGHEI), joint center for bioethics (JCB) }\end{array}$ & $\begin{array}{l}\text { MPH } \\
\text { MSCCH } \\
\text { MSC MHSC } \\
\text { Ph.D. }\end{array}$ \\
\hline
\end{tabular}




\section{Training Mode for Master of Health Administration}

\section{Training Objective}

The training objective is the quality standards for graduate students, which will directly affect the length of schooling, curriculum setting. It is the main index to test whether students meet the training requirements, which is the principle and guiding ideology of curriculum setting and reform. Taking Harvard University as an example, the curriculum for the Health Administration program stemmed from its mission to prepare individuals for leadership in complex and dynamic health care environments ${ }^{[4]}$.

As shown in table 2, the training objectives for graduate students in Health Administration program in North America were specifically set for different majors. There was a significant difference between academic and professional degree program in the training objective. Taking Johns Hopkins University for example, the professional program was designed to develop health care leaders, like policy makers, senior management, information specialists; While the academic program focused on academic research ability, combining the student's academic training with the real-world practice, cultivating analysis, implementation, and evaluation. Thus, academic program emphasized the conceptual, analytical, and applied skills required to advance into management careers in hospitals and health systems, while professional program focused on management and leadership development.

Table 2 Training objective for Master of Health Administration in North America

\begin{tabular}{|c|c|c|}
\hline $\begin{array}{l}\text { Name } \\
\text { University }\end{array}$ & Degree programs & Training objective \\
\hline $\begin{array}{l}\text { Harvard } \\
\text { University }\end{array}$ & $\begin{array}{l}\text { Master of Science in } \\
\text { Health Policy and } \\
\text { Management (HPM) }\end{array}$ & $\begin{array}{l}\text { To pursue health policy research and for } \\
\text { students interested in domestic or } \\
\text { international research questions. }\end{array}$ \\
\hline $\begin{array}{l}\text { Harvard } \\
\text { University }\end{array}$ & $\begin{array}{l}\text { Master of Public Health } \\
\text { (Health } \quad \text { Management } \\
\text { Field/ Health Policy Field ) }\end{array}$ & $\begin{array}{l}\text { To gain specialized expertise in particular } \\
\text { areas that match their public health interests, } \\
\text { professional goals, and prior experience. }\end{array}$ \\
\hline $\begin{array}{l}\text { Harvard } \\
\text { University }\end{array}$ & $\begin{array}{l}\text { Master in Health Care } \\
\text { Management (HCM) }\end{array}$ & To develop health care leaders \\
\hline $\begin{array}{l}\text { Johns Hopkins } \\
\text { University }\end{array}$ & $\begin{array}{l}\text { Master of Health } \\
\text { Administration }\end{array}$ & $\begin{array}{l}\text { To develop health care leaders for a rapidly } \\
\text { changing world }\end{array}$ \\
\hline $\begin{array}{l}\text { Johns Hopkins } \\
\text { University }\end{array}$ & $\begin{array}{l}\text { The Master of Health } \\
\text { Science (MHS) in Health } \\
\text { Economics and Outcomes } \\
\text { Research }\end{array}$ & $\begin{array}{l}\text { To pursue careers in academia, government, } \\
\text { and industry; further doctoral training in } \\
\text { economics and health policy }\end{array}$ \\
\hline $\begin{array}{l}\text { Johns Hopkins } \\
\text { University }\end{array}$ & $\begin{array}{l}\text { Master of Health Science } \\
\text { in Health Finance and } \\
\text { Management }\end{array}$ & $\begin{array}{l}\text { To achieve value-based health care in pursuit } \\
\text { of continuous quality improvement }\end{array}$ \\
\hline $\begin{array}{l}\text { Johns Hopkins } \\
\text { University }\end{array}$ & Master of Public Policy & $\begin{array}{l}\text { To emphasize analytic thinking through } \\
\text { policy choices, formulation, implementation } \\
\text { and evaluation }\end{array}$ \\
\hline $\begin{array}{l}\text { Toronto } \\
\text { University }\end{array}$ & $\begin{array}{l}\text { Master of Science in } \\
\text { Public Health in Health } \\
\text { Policy }\end{array}$ & To develop health care leaders \\
\hline
\end{tabular}

\section{Degree Program}

In North America, the schooling length for master of Health Administration was generally 1 or 2 years. The eligibility requirements of different degrees were different, mainly as follows. Firstly, degree program designed for students who hold a medical degree or have relevant work experience in the field of public health or a related field. Secondly, academic programs focused on developing analytic and quantitative skills, while professional programs trained students the problem-solving skills needed to address a wide variety of challenges throughout the health care delivery, public policy, 
and public health systems. Moreover, the internship designed to fit the needs of students with different education goals (Table 3). The curriculum for Master of Health Administration program stemmed from its mission to prepare individuals for leadership in complex and dynamic health care environments.

Table 3 Eligibility and requirements for Master of Health Administration in North America

\begin{tabular}{|c|c|c|c|}
\hline $\begin{array}{l}\text { Name of } \\
\text { University }\end{array}$ & $\begin{array}{l}\text { Degree } \\
\text { programs }\end{array}$ & Eligibility & $\begin{array}{l}\text { Length of schooling and } \\
\text { credits }\end{array}$ \\
\hline $\begin{array}{l}\text { Harvard } \\
\text { University }\end{array}$ & $\begin{array}{l}\text { Master } r \text { of } \\
\text { Science } \quad \text { in } \\
\text { Health Policy } \\
\text { and } \\
\text { Management } \\
(\text { HPM) }\end{array}$ & $\begin{array}{l}\text { Designed for individuals with } \\
\text { doctoral degrees in medicine, } \\
\text { dentistry, or other health-related } \\
\text { disciplines who are pursuing research } \\
\text { careers and desire intensive exposure } \\
\text { to analytic and quantitative skills. }\end{array}$ & 1year. At least 42.5 credit \\
\hline \multirow[t]{2}{*}{$\begin{array}{l}\text { Harvard } \\
\text { University }\end{array}$} & \multirow{2}{*}{$\begin{array}{l}\text { Master of Public } \\
\text { Health (Health } \\
\text { Management } \\
\text { Field/ Health } \\
\text { Policy Field ) }\end{array}$} & $\begin{array}{l}\text { Hold a g raduate degree or have at } \\
\text { least five years of relevant work } \\
\text { experience in the field of public health } \\
\text { or a related field. }\end{array}$ & $\begin{array}{l}2 \text { semesters (one academic } \\
\text { year) as a full-time student. } \\
\text { At least } 42.5 \text { credits }\end{array}$ \\
\hline & & $\begin{array}{l}\text { Hold a bachelor's degree and at least } \\
\text { two years of relevant work experience } \\
\text { in public health or a related field. }\end{array}$ & $\begin{array}{l}3 \text { semesters as a full-time } \\
\text { student. At least } 65 \text { credits }\end{array}$ \\
\hline $\begin{array}{l}\text { Harvard } \\
\text { University }\end{array}$ & $\begin{array}{l}\text { Master in Health } \\
\text { Care } \\
\text { Management } \\
(\mathrm{HCM})\end{array}$ & $\begin{array}{l}\text { mid-career MDs, DMDs, and DDSs } \\
\text { with significant management } \\
\text { responsibilities }\end{array}$ & $\begin{array}{l}2 \text { years. At least } 42.5 \\
\text { credits }\end{array}$ \\
\hline $\begin{array}{l}\text { Johns } \\
\text { Hopkins } \\
\text { University }\end{array}$ & $\begin{array}{l}\text { Master of Health } \\
\text { Administration ( } \\
\text { MHA) }\end{array}$ & $\begin{array}{l}\text { Prepared students for high-level } \\
\text { careers in hospitals, health systems, } \\
\text { top-tier consulting firms and } \\
\text { healthcare businesses }\end{array}$ & $\begin{array}{l}2 \text { years, including } 1 \text {-year } \\
\text { schooling and11-month } \\
\text { internship }\end{array}$ \\
\hline $\begin{array}{l}\text { Johns } \\
\text { Hopkins } \\
\text { University }\end{array}$ & $\begin{array}{l}\text { Master of Health } \\
\text { Science (MHS) }\end{array}$ & $\begin{array}{l}\text { Prepared students for further graduate } \\
\text { work or research careers }\end{array}$ & $\begin{array}{l}1 \text { year, including 9-month } \\
\text { schooling. At least } 70 \\
\text { credits }\end{array}$ \\
\hline $\begin{array}{l}\text { Johns } \\
\text { Hopkins } \\
\text { University }\end{array}$ & $\begin{array}{ll}\text { Master } & \text { of } \\
\text { Science } & \text { in } \\
\text { Public } & \\
\text { Health }(\mathrm{MSPH}) \\
\end{array}$ & $\begin{array}{l}\text { For students who want more focused } \\
\text { skills in a specific field of public } \\
\text { health or who lack two years of health } \\
\text { related work experience }\end{array}$ & $\begin{array}{l}1 \text { year, including 9-month } \\
\text { schooling }\end{array}$ \\
\hline $\begin{array}{l}\text { Johns } \\
\text { Hopkins } \\
\text { University }\end{array}$ & $\begin{array}{l}\text { Master of Public } \\
\text { Policy (MPP) }\end{array}$ & $\begin{array}{l}\text { For college graduates, middle-level } \\
\text { professionals, peace corps workers, } \\
\text { etc. }\end{array}$ & $\begin{array}{l}2 \text { years, including } \\
\text { 300-hour internship. At } \\
\text { least } 96 \text { credits }\end{array}$ \\
\hline $\begin{array}{l}\text { Toronto } \\
\text { University }\end{array}$ & $\begin{array}{l}\text { Master of Health } \\
\text { Science in } \\
\text { Health } \\
\text { Administration }\end{array}$ & $\begin{array}{l}\text { For those seeking a leadership role in } \\
\text { the healthcare system with the } \\
\text { necessary knowledge, skills and } \\
\text { strategic perspective. }\end{array}$ & $\begin{array}{l}2 \text { years, including } 8 / 12 \\
\text {-week internship. }\end{array}$ \\
\hline
\end{tabular}

\section{Focused on Core and Professional Courses}

On one hand, the curriculum based on academic ability, such as, biostatistics and epidemiology as the core curriculum with more than five credits at Harvard University. Johns Hopkins University also attached importance to statistics and epidemiology, especially statistics. Three semesters' study in statistics was required for students who want to seek for Master of Health Administration (MHA), Master of Health Science (MHS), or Master of Public Policy (MPP).

On the other hand, students' academic ability were fully strengthened. Take Harvard for example, students must take an additional 10 credits in Economic Analysis, Quality of Care, and Health Decision Sciences, and complete an additional $5 \mathrm{c}$ redits of supervised independent study under direction of a supervisor. 


\section{Emphasized on Management and Leadership Training}

Students' abilities were fully developed by the course training, especially management and leadership.

All courses in Toronto University had clearly articulated learning objectives, which were based on the competencies viewed as necessary to leading in health care environments. These competencies demonstrated the importance of credibility, creativity, and the ability to engage and motivate in complex and dynamic health care environments ${ }^{[5]}$. The Program gave particular emphasis to 14 competencies that most closely reflect its mission and the views of stakeholders, including leadership, collaboration, communication skills, and organizational awareness etc. ${ }^{[6]}$

In Johns Hopkins University, students must complete the course work and administrative residency. In terms of technical analysis, financial, economic, market and performance information and models were applied to improve and optimize organizational performance. In the healthcare environment domain, students can learn knowledge of the healthcare system and environment in which health services are provided. In management and leadership practice domain, coursework were applied to establish and achieve organizational goals, like Health Services Management, Leadership, Human Resources Management etc. ${ }^{[7]}$

\section{Related Closely with Real-World}

Case-based teaching method was widely applied, combined with extensive peer collaboration, the degree program kept students on top of trends, issues and competitive strategies unique to the modern health care system. Homework can be done by email or Internet, which is accomplished within a highly collaborative, small-group learning environment.

Residency experience was required. In the second year of the MHA program, students at Johns Hopkins University were placed in eleven-month full-time residency positions which include salary and benefits. During the field placement year, students become members of an organization's executive management team and work on important assignments, make meaningful contributions and learn valuable lessons in how health care works. In Toronto University, practicum placements delivered valuable experiential learning under the supervision and mentorship of top health sector executives.

\section{Inspiration from the Training Model for MHA in North America}

The characteristics of training model for MHA in North America had multiple inspirations for the reform of training model for MHA in China.

\section{Identified Specific Training Objectives}

Articulated training objectives for MHA program combined with practical demands. Based on this, each link of the training model was determined, including eligibility, credits requirements, coursework and residency experience. At present, the training objectives of MHA in China were too general, and there was little difference between academic and professional talents. Therefore, more specific training objectives were very important, not only to guide the curriculum, but also to develop students' professional ability.

\section{Built Competency-Based Curriculum System}

Established in the public health background, it was particularly important to cultivate students' professional ability of management and leadership. All courses should have clearly articulated learning objectives, which were based on the necessary competencies in health care environments. Leadership development provided learning opportunities for learners through academic lectures, reading report and other forms of active participation, which was a continuous process required specific practice through the exploration of problem-oriented and case-based teaching method. 


\section{Developed Practice Ability}

With distinctive characteristics of practice ability, course in North America closely related with the hot issues in healthcare field. Most tasks, whether classroom activities or evaluation methods, were designed to require students to complete investigation or simulation of the real world. Besides, the ability of putting theory into practice was paid much attention. The MHA program in China clearly stipulated that graduate students must participate in practice, however, regulation was just externalism. Therefore, in the future we should pay attention to the students' professional ability and expertise, and encourage them to find problems and solve problems in practice.

\section{References}

[1] Harvard. Degree Programs - Admissions [EB/OL]. [2016-8-2]. https://www.hsph.harvard.edu/admissions/degree-programs/.

[2] School Of Public Health J H B. Degree Programs - Academics [EB/OL]. [2016-8-10]. http://www.jhsph.edu/academics/degree-programs/.

[3] Dalla Lana School Of Public Health. Our Programs [EB/OL]. [2016-8-8]. http://www.dlsph.utoronto.ca/programs/.

[4] Department Of Health Policy And Management H T H C. Academic Programs [EB/OL]. [2016-8-8]. https://www.hsph.harvard.edu/health-policy-and-management/academic-programs/.

[5] Curriculum. MHSc-webinar-Dec-9-2015[EB/OL].

[2016-8-15]. http://ihpme.utoronto.ca/wp-content/uploads/2016/01/MHSc-webinar-Dec-9-2015.pdf.

[6] Institute Of Health Policy M A E. Program Curriculum [EB/OL]. [2016-8-20]. http://ihpme.utoronto.ca/academics/pp/mhsc/program-curriculum/.

[7] Johns Hopkins Bloomberg School Of Public Health. MHA Competency Model [EB/OL]. [2016-8-15].http://www.jhsph.edu/departments/health-policy-and-management/degree-programs/ma ster-of-health-administration/competencies. 